\title{
Magnetotelluric study in the Los Lagos Region (Chile) to investigate volcano-tectonic processes in the Southern Andes
}

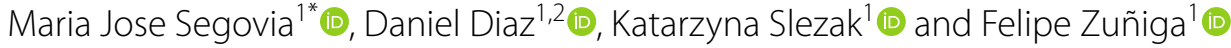

\begin{abstract}
To analyze the process of subduction of the Nazca and South American plates in the area of the Southern Andes, and its relationship with the tectonic and volcanic regime of the place, magnetotelluric measurements were made through a transversal profile of the Chilean continental margin. The data-processing stage included the analysis of dimensional parameters, which as first results showed a three-dimensional environment for periods less than $1 \mathrm{~s}$ and two-dimensional for periods greater than $10 \mathrm{~s}$. In addition, through the geomagnetic transfer function (tipper), the presence of structural electrical anisotropy was identified in the data. After the dimensional analysis, a deep electrical resistivity image was obtained by inverting a 2D and a 3D model. Surface conductive anomalies were obtained beneath the central depression related to the early dehydration of the slab and the serpentinization process of the mantle that coincides in location with a discontinuity in the electrical resistivity of a regional body that we identified as the Nazca plate. A shallow conductive body was located around the Calbuco volcano and was correlated with a magmatic chamber or reservoir which in turn appears to be connected to the Liquiñe Ofqui fault system and the Andean Transverse Fault system. In addition to the serpentinization process, when the oceanic crust reaches a depth of 80-100 km, the ascending fluids produced by the dehydration and phase changes of the minerals present in the oceanic plate produce basaltic melts in the wedge of the subcontinental mantle that give rise to an eclogitization process and this explains a large conductivity anomaly present beneath the main mountain range.
\end{abstract}

Keywords: Magnetotellurics, Osorno volcano, Calbuco volcano, Subduction zone processes, Serpentinization, Eclogitization

\section{Key points}

Electrical resistivity images of the Los Lagos region, Chile

Two- and three-dimensional models of the electrical resistivity structure of the Southern Andes subduction zone $\left(41^{\circ} \mathrm{S}\right)$.

Processes of generation, Migration and accumulation of fluids

Serpentinization and eclogitization processes

\footnotetext{
*Correspondence: masegovia@ug.uchile.cl

1 Departamento de Geofísica, Universidad de Chile, Blanco Encalada

2002, Santiago, Chile

Full list of author information is available at the end of the article
}

\section{Introduction}

The Southern Andes constitute an orogenic mountain belt developed on an active continental margin, with subduction between the Nazca and South American tectonic plates as the main cause of the magmatic and tectonic processes in the area (Hervé, 1994). The area of study is framed in the Southern Volcanic Zone of the Andes (SVZ), in this zone, the complex interaction between tectonic and magmatic processes is evident in the architecture and geochemical signature of the volcanic systems, and Cembrano and Lara (2009) relate this spatial distribution of plutons, dikes and volcanic cones, with the lithospheric stress generated by the Liquiñe Ofqui Fault System. The Liquiñe Ofqui Fault Zone (LOFZ) 
corresponds to a strike-slip system of approximately $1200 \mathrm{~km}$ long, where most of the seismic activity of the continental crust in the South of Chile is concentrated (Lavenu and Cembrano 1999). The South of Chile represents an attractive place for a volcano-tectonic study; since it is located in an orogenic margin, with an important system of faults dominating the terrestrial crust and active volcanic centers, it appears as a favorable environment for the development of natural disasters related to volcanoes and earthquakes. Arc volcanism and seismic activity are closely related to the distribution of fluids from physical-chemical processes that occur in subduction (Saffer 2017).

The process of generating magmatic fluids that migrate through the continental crust depends on some physical parameters of the oceanic plate such as its composition, thickness, angle of inclination with which it subducts and its degree of hydration, which in turn depends on the age and porosity of the plate (Völker and Stipp 2015). As the oceanic slab subduces the continental slab, due to the increase of temperature and pressure conditions, mineralogical changes are generated as a result of the dehydration of the Nazca plate. One of the most significant processes corresponds to the serpentinization process of the mantle, in which a metamorphic alteration is produced that affects the ultramafic rocks of the upper mantle. In seismic studies, the serpentinization zones can be observed as zones where the seismic velocity of $\mathrm{S}$ wave, and the density of the mantle is drastically reduced (Hyndman and Peacock 2003). Serpentinization can also generate seismic reflectivity, increased magnetization and a reduction in mechanical strength (Hyndman and Peacock 2003). The other important process corresponds to eclogitization that occurs at greater depths where the temperature and pressure conditions are extreme, and in this process, all the remaining water present in the slab forming minerals is released (Leech 2001). The serpentined and eclogitized zones are clearly shown in seismic tomography and in resistivity images measured with the magnetotelluric method. Examples of works where these processes can be identified by geophysical methods are those of Reynard et al. (2011), Navarro (2019), Evans et al. (2014), Wannamaker et al. (2014), Kapinos et al. (2016) and Cordell et al. (2019).

As the oceanic slab dehydrates, through processes of serpentinization and eclogitization, fluids are generated that rise and fall the melting point of the continental crustal rock, forming magmatic fluids that migrate and control the creation of volcanoes in the arcs. These fluids can be transported through fault networks to the surface of the Earth (Clemens and Mawer 1992). Therefore, the stress of the lithosphere influences the spatial distribution of plutons, dikes and volcanic cones.
The magnetotelluric method is useful in the study of the above processes because the conductivity of the crust and mantle rocks increases with the presence of fluids, and it is one of the few geophysical methods that can penetrate to the depths at which these processes are generated.

The present work seeks to study the lithospheric structure of electrical resistivity in the Southern Andes to analyze processes of generation, migration and accumulation of fluids related to the subduction between the Nazca and South American plates in the Chilean continental margin.

\section{Geological setting}

The oceanic Nazca plate subducts beneath the continental South American plate along the Andes with a convergence rate of $6.6 . \mathrm{cm} /$ year and an azimuth of $77^{\circ}$ (Angermann et al. 1999). In the SVZ between $33^{\circ} \mathrm{S}$ and $46^{\circ} \mathrm{S}$ latitude, the Nazca plate has a subduction angle of $\sim 20^{\circ}$ (Tassara and Echaurren 2012). The stretch of oceanic plate between $40.5^{\circ} \mathrm{S}$ and $41.5^{\circ} \mathrm{S}$ and around $75^{\circ} \mathrm{W}$ longitude has an age of 18.3 Ma (Völker and Stipp 2015).

In Fig. 1, from West to East, the main morphological units are given by The Coastal Range, south of $38^{\circ} \mathrm{S}$, which is an accretionary prism metamorphosed in late Paleozoic to late Triassic times (Thomson and Hervé 2002). The eastern flank of the Coastal Range is characterized by intrusive and volcanic-sedimentary Mesozoic sequences suggesting the eastward migration of the volcanic arc from the Jurassic; the Depression or Central Valley, which constitutes the extension of the OsornoLlanquihue basin towards the south, contains approximately $4 \mathrm{~km}$ of Cenozoic marine volcanic rocks and glacial sediments in a 70-km-wide depocenter parallel to the trench (Jordan et al. 2001); the eastern limit of the Central Depression is defined by the North Patagonian Batholith and the current Volcanic Arc in the Northern Patagonian Andes, where the Liquiñe Ofqui Fault Zone is developed. The Batholith is $2000-\mathrm{km}$ long and $200-\mathrm{km}$ wide, it is composed mainly of plutonic alkaline rocks from the Middle Jurassic to the Miocene (Glodny et al. 2008). The main water bodies in the study area are the lakes of glacial origin, Llanquihue Lake (L.LL) and Todos Los Santos Lake (L.TS). In the Southern Volcanic Zone of the Andes, cortical level structures related to the LOFZ and Andean Transverse Fault (ATF) have been identified. The oblique convergence between the Nazca and South American plates is the main cause of the transpressive dextral deformation in the Earth's crust, dominated by the sliding of regional to local scale by these fracture networks.

The LOFZ is associated with a dextral transpressive regime from at least the last $6 \mathrm{Ma}$ (Cembrano et al. 1996), 


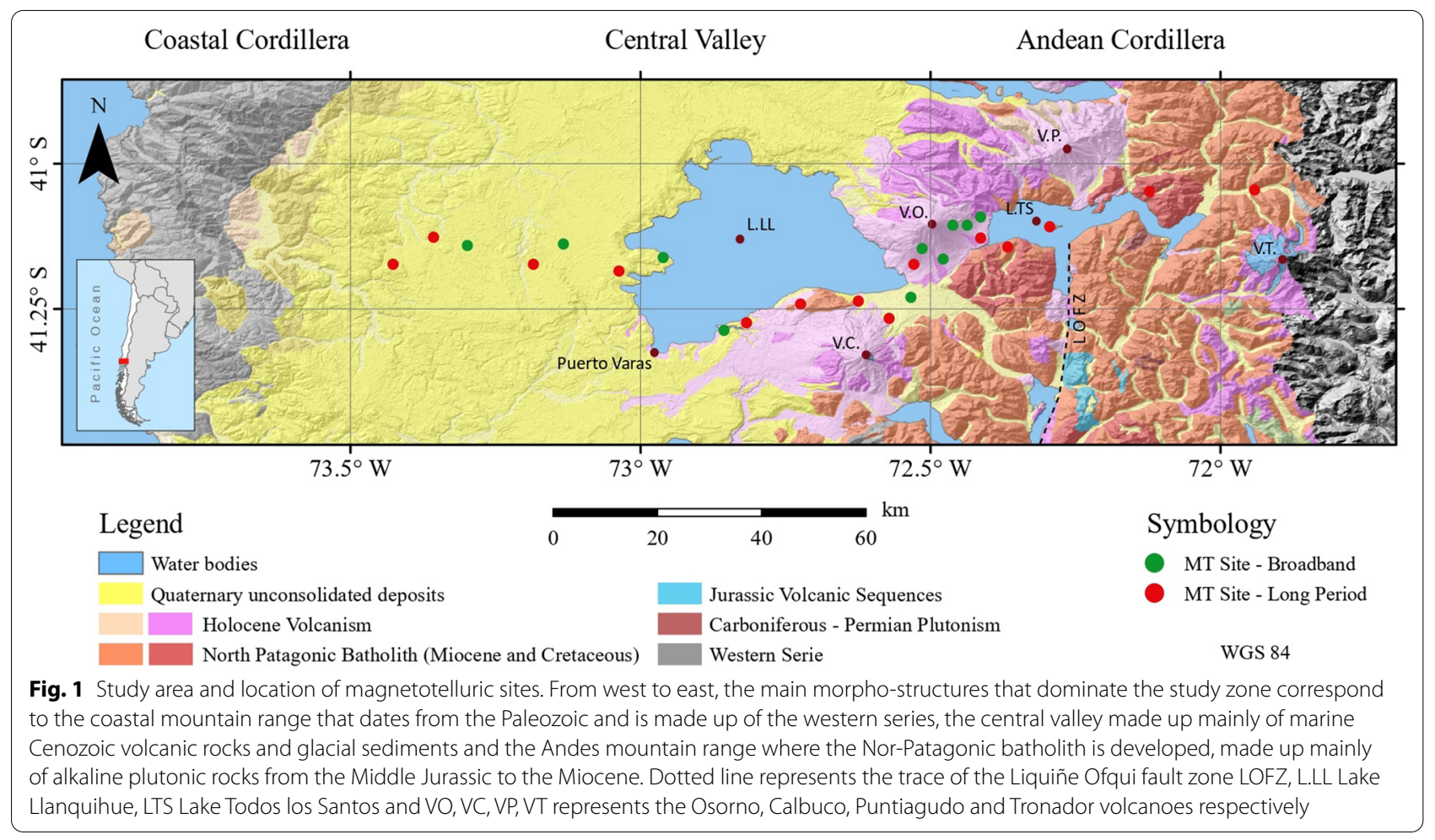

extending from the town of Liquiñe $\left(39^{\circ} \mathrm{S}\right)$ to the isthmus of Ofqui $\left(47^{\circ} \mathrm{S}\right)$. At latitude $41^{\circ} \mathrm{S}$, Lavenu and Cembrano (1999) attribute a vertical geometry to the fault line, generated by dextral transpressive systems of $\mathrm{N}-\mathrm{S}$ orientation, with double vergence, developed between the Neogene and Quaternary. The LOFZ is characterized by sub-vertical NNE-oriented master segments and transtensional faults from ENE to EW (Cembrano and Hervé 1993).

Most, if not all, of the volcanic systems at the top of the LOFZ are monogenetic, suggesting that they were formed by geologically instantaneous events (Cembrano and Lara 2009).

Another important fault system to highlight in the Southern Volcanic Zone corresponds to the Andean Transverse Fault, these include a series of NW oriented faults, probably inherited from a pre-Andean architecture with inverse sinistral kinematics and local reactivation of normal sliding (Radic 2010). It is suggested that the ATF is older, dating from the pre-Andean, or equivalent to the LOFZ (Pankhurst et al. 2006).

Fracture networks or faults in the continental crust have been considered as an efficient route through which fluids are transported to the earth's surface (Clemens and Mawer 1992). Therefore, the lithospheric stress influences the spatial distribution of plutons, dikes and volcanic cones. However, crustal deformation not only plays an important role in magma migration. More importantly, it can exert fundamental control over magma-differentiation processes which, in turn, can determine the nature and composition of volcanism along continental margins.

The volcanic zone of the Southern Andes is located between $33^{\circ} \mathrm{S}$ and $46^{\circ} \mathrm{S}$. The complex interaction between tectonic and magmatic processes is evidenced by both the architecture and the geochemical signature of the volcanic buildings in this zone. Throughout the SVZ strike, variations in the composition of the products of the volcanoes and in their orientation are evident. The structures of NE-SW orientation and originating mostly from primitive magmas belong to stratovolcanoes and monogenetic cones associated to LOFZ guidelines while stratovolcanoes of WNW orientation and with compositional products from basaltic to rhyolitic rocks are associated to structures of the ATF (Cembrano and Lara 2009). The main factors that explain the variations along the strike in the nature and composition of volcanism are the variation in crust thickness, the source of magma, the lithospheric nature and structure and the existence of a predominant intra-arc fault system (Cembrano and Lara 2009). The thickness of the crust below the volcanic arc is approximately $50 \mathrm{~km}$ at latitude $33^{\circ} \mathrm{S}$ and decreases towards the South, reaching a thickness of $35 \mathrm{~km}$ at $46^{\circ} \mathrm{S}$ (Tassara and Yañez 2003). 
One of the most important volcanoes for its activity in the area corresponds to the Calbuco volcano (2003 m.a.s.l.), it is built on a base of Miocene granite and meta-sedimentary mafic igneous rocks of the Upper Paleozoic and, unlike most of the volcanoes of the Southern Andes, it is located west of the main route of the Liquine Ofqui Fault Zone, and is not clearly related to or controlled by regional structures. Its documented historical activity includes at least 12 eruptive cycles, 4 of which in the twentieth century included effusive and explosive activity. The highly hydrated magmas that characterize the volcano's petrology increase its potential to generate explosive eruptions. The main hazards are associated with the volcano, however, there are the evidences of lahars and block and ash flows, mainly directed towards the fans to the Northeast, South and Southeast, in areas with growing population and infrastructure development (Selles and Moreno 2011). In April 2015, the last volcanic eruption of the Calbuco was recorded. According to studies such as Castruccio et al. (2016), the erupted products were mainly basaltic andesites. Another important volcanic structure to mention in our study area corresponds to the Osorno stratovolcano belonging to the Middle Pleistocene (<ca. 200 ka). Together with the La Picada, Puntiagudo and Cordón Cenizos volcanoes, it forms a transversal volcanic chain of $\mathrm{N}^{\circ} 0^{\circ} \mathrm{E}$ orientation. The eruptions of the central crater, Osorno volcano, have generated basaltic pyroclastic flows and tephras of dacitic composition that date from the Holocene $(<10 \mathrm{ka})$ and are distributed in a wide sector around the volcano. The historical eruptive activity of the Osorno volcano has been essentially characterized by low explosive episodes among which the fissural eruption of 1835 AD stands out (Moreno et al. 2010).

Other volcanic centers in our study area correspond to the Puntiagudo and Tronador stratovolcanoes. The former stands out for the prominent lava, pyroclastic and laharsic deposits, while the latter for a large glacier on its summit. It is known that glaciers play a critical role in the violent interaction between magma and water, generating explosive reactions (Mella et al. 2005).

\section{Methods}

\section{Magnetotelluric data}

Magnetotellurics (MT) is an electromagnetic method of geophysical exploration used to deduce the electrical resistivity structure of the Earth at depths ranging from tens of meters to hundreds of kilometers. This method uses a source signal of external origin, natural variations of electric and magnetic fields of the Earth, generated by physical processes such as solar variations and magnetic storms. The spectra of these variations cover periods ranging from $10^{-3}$ to $10^{5}[\mathrm{~s}$ ] and are generated by the interaction between the solar wind, the magnetosphere and the ionosphere of planet Earth (Vozoff 1991).

The MT method is based on the simultaneous measurement of the total electromagnetic field, i.e., the time variation of the magnetic field $B(t)$ and the induced electric field $E(t)$. The electrical properties of the underlying material can be determined from the relationship between the components of the measured variations of electric $(E)$ and magnetic $(B)$ fields, or transfer functions: the horizontal electric $\left(E_{x}\right.$ and $\left.E_{y}\right)$ and the horizontal magnetic $\left(B_{x}\right.$ and $\left.B_{y}\right)$ and vertical $\left(B_{z}\right)$ field components. The transfer functions consist of a complex impedance tensor which relates the measured electric field components to the magnetic field components and a geomagnetic transfer function which is often called a tipper and relates the horizontal magnetic field components to the vertical magnetic field component. In general, the resistivity structure of the earth is three-dimensional obtaining a complex impedance tensor of four components, however, if it is a two-dimensional structure where the resistivity does not vary along the geoelectric strike, the diagonal components of the tensor are null as long as the coordinate system is parallel to the strike direction. In this case, the two surviving tensor components are related to two independent modes, the magnetic transverse (TM) and the electric transverse (TE). Sometimes if the strike preference angle is known, the tensor can be rotated so that the diagonal components are minimized. Generally, the elements of the impedance tensor can be plotted as apparent resistivity and phase as a function of period (reciprocal of frequency), and these graphs can give us an idea of variations in the average resistivity of the medium that has been measured so that short periods are related to shallow depths and long periods to greater depths. Some components of the measured electric fields can be affected by a phenomenon called Static Shift that is a galvanic distortion effect that locally shifts apparent resistivity sounding curves by a scaling factor that is independent of the frequency, keeping the phases unchanged. This effect is caused by charge accumulation at boundaries of shallow conductive heterogeneities, which disturb the regional electric field locally (Tournerie et al. 2007). On the other hand, the geomagnetic transfer function serves to identify lateral resistivity contrasts and can be represented as arrows or induction vectors, under the convention of Wiese (1962) the vectors point in the opposite direction to the conducting body. When making long-period measurements near the ocean, it is expected to observe the so-called shore effect on the induction vectors for long periods. Due to the large resistivity contrast between the ocean and the continent the orientation of the 
vectors over longer periods should be expected to be in the opposite direction and perpendicular to the shore.

To obtain a lithospheric model of the electrical resistivity structure of the study area, several field campaigns were carried out between December 2018 and April 2019, where 14 long-period and 10 broadband stations were installed along the profile transverse to the coast (Fig. 1). Three types of instruments were used to carry out the measurements, ADU (Analog/Digital Signal Conditioning Unit) with induction coils MFS-07e and electrodes EFP-06, manufactured by Metronix geophysics; NIMS (Narod Intelligent Magnetotelluric Systems) with Triaxial ring-core magnetometer and $\mathrm{OSU} \mathrm{Pb}-\mathrm{PbCl} 2$ gel-type electrodes; and instruments Lemi417 with non-polarized electrodes Lemi-701 and Flux Gate sensor Lemi-424 manufactured by LEMI LLC. All stations were oriented with a geomagnetic coordinate system. The data processing included the application of filters to the obtained time signals to eliminate noise signals where possible, remote reference application in some cases to improve the data quality of the stations that were measuring simultaneously. The signals obtained with ADU stations were processed with the robust process developed by Egbert and Booker (1986), those obtained from NIMS stations were processed with the code developed by Egbert and Livelybrooks (1996) and the signal obtained with Lemi stations were processed with the robust code developed by Egbert (1997).

We proceeded to calculate the strike in period intervals for all stations with the code developed by Smith (1995) to know if there was any preferential direction of the structure and to diagnose a possible two-dimensional space. In Fig. 2, it can be seen that for the range of periods between $10^{-3}$ and $10^{0} \mathrm{~s}$, the structure does not have a preferential orientation, evidencing a threedimensional environment, while for periods greater than $1 \mathrm{~s}$ the structure begins to behave two-dimensionally. In Fig. 3, the induction vectors are plotted in a length vs period profile where we can observe characteristic behaviors of areas where we expect to find conductive bodies in the inversion models. The small magnitude of the arrows enclosed by the dotted celestial line and the W-E direction of the arrows enclosed by the purple line suggests a conductive zone towards the west of the Llanquihue Lake, the direction of the vectors enclosed by the pink dotted line could be indicating the presence of a conductive body around the Osorno volcano, while the magnitude of the arrows enclosed by the green dotted line indicates the presence of a body of low resistivity in the Andes mountain range.

For long periods $\left(>10^{1} \mathrm{~s}\right)$, the arrows were expected to have a regional behavior in $\mathrm{W}-\mathrm{E}$ direction due to the coast effect, however, it can be observed in the vectors delimited by the yellow dotted line that have a SWNE direction. This behavior of the vectors is studied by Brasse et al. (2009) in the Chilean continental margin, between latitudes $38^{\circ}$ and $41^{\circ} \mathrm{S}$, and they attribute it to the resultant between the effect of the ocean and the presence of a layer with structural electrical anisotropy in the crust. Anisotropy was also identified in some phase curves that escaped their natural quadrant
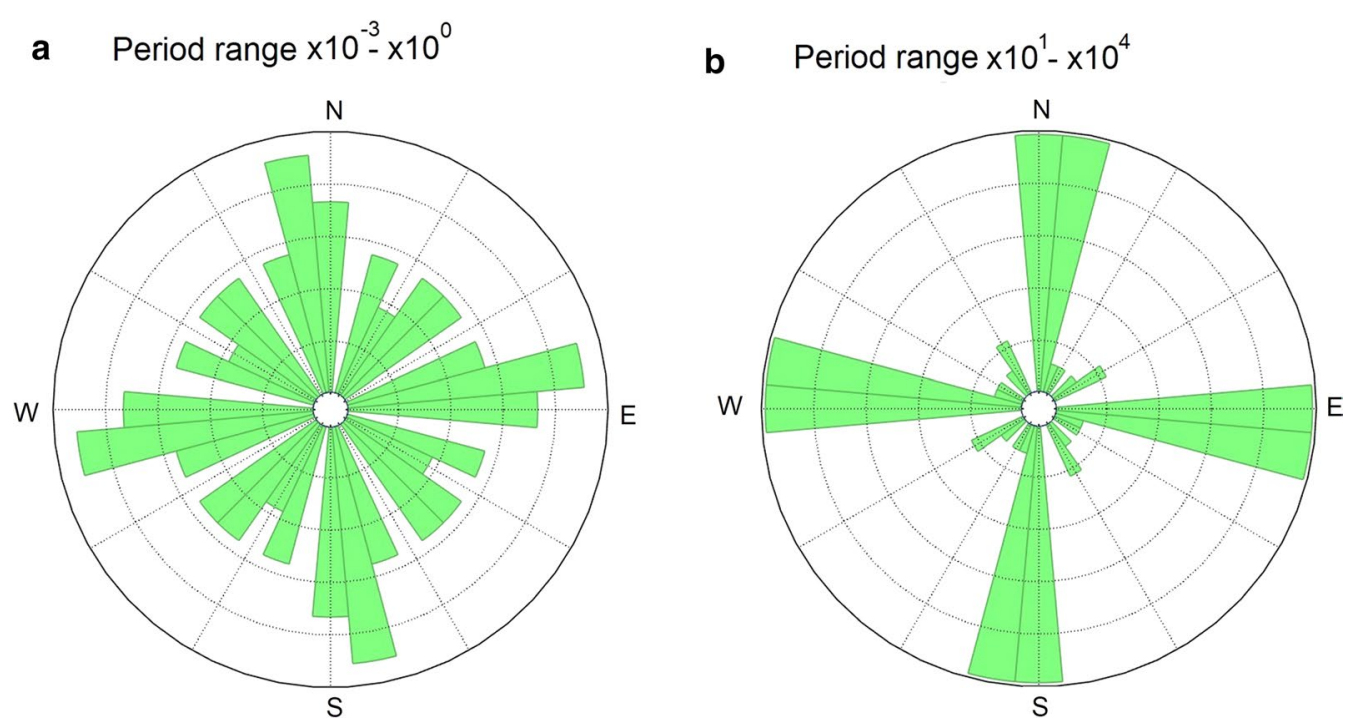

Fig. 2 Geoelectric strike for two period ranges. a The geoelectric strike for sites with periods between $10^{-3}$ and $10^{0} \mathrm{~s}$. b The geoelectric strike for sites with periods between $10^{1}$ and $10^{4} \mathrm{~s}$ 


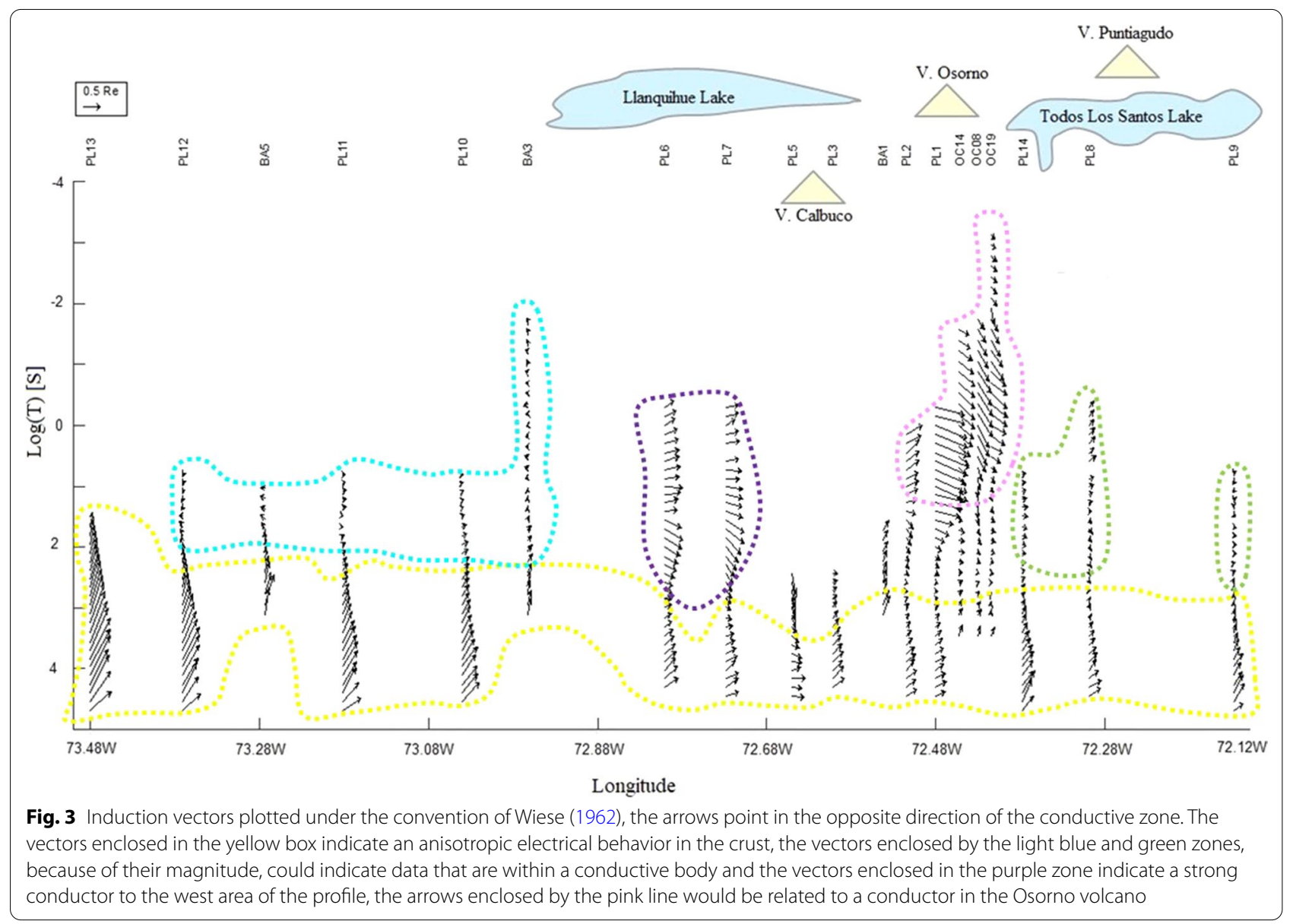

(see Additional files). However, phases out of quadrant can also be explained by strong galvanic distortion, 2D structures with high resistivity contrasts, and 3D conductive bodies generating strong current channeling or a superposition of different effects (Martí 2014).

An electrically anisotropic medium can be, for example, a space influenced by micro-scale hydrated faults that can become a macro-scale structure if these structures have a preferential general orientation. From the above, it can be inferred that one way to mitigate the effect of anisotropy on the data is to work with the periods between $10^{1}$ and $10^{4} \mathrm{~s}$, since this range has a general preferential strike (Martí 2014).

\section{Magnetotelluric data inversion}

We carried out 2D and 3D inversions to obtain a realistic model that is close to the geology of the region. In addition, Martí (2014) recommends testing different inversion software, different models and altering different parameters in the inversions until we obtain models without artifacts resulting from structural electrical anisotropy.
For the two-dimensional inversion, we used the WinGlink software that uses the 2D inversion code from Rodi and Mackie (2001), this algorithm minimizes an objective function, by means of the non-linear conjugate gradient method (NLCG), which penalizes the differences between the data and the model response, to obtain a contrast of resistivities in a smooth model. Taking into account the dimensional analysis performed previously, the dataset was chosen between the range of periods $10^{1}$ and $10^{4} \mathrm{~s}$. The field measurements were made with respect to the magnetic North and the general strike calculated for periods greater than $10 \mathrm{~s}\left(\mathrm{~N}^{\circ} \mathrm{E}\right)$ is approximate to the geological structures in the area, so it was decided not to rotate the data since it is assumed that the regional resistivity structure can approximate a $2 \mathrm{D}$ structure that varies in the $\mathrm{E}-\mathrm{W}$ direction, parallel to our profile. As the anisotropy is mostly reflected in the induction vectors, it was chosen to model only the TE and TM mode impedance data.

Background resistivities of 100 and $500 \Omega \mathrm{m}$ were tested. For longer periods, the same result in both tests were performed. The minimum frequency used was 
$0.00008 \mathrm{~Hz}$, error floors were set to $20 \%$ for apparent resistivities and $5 \%$ for phases. A fine grid with growth factor 1.2 was used in depth and to the sides of each station. Although, the topography option was activated, it is not influential in the inversion when working with longperiod data. Some initial tests were performed varying the regularization factor until a tradeoff between roughness and RMS was found, the value was set to $\tau=8$.

To the initial inversion known information of the zone was delivered, an ocean was drawn with a resistivity of $0.3 \Omega \mathrm{m}$ and a mean depth of $5 \mathrm{~km}$ according to the bathymetry registered by the National Oceanic and Atmospheric Administration (http://www.ngdc.noaa. gov/mgg/topo/topo.html).

To mitigate the impact of anisotropy on data, separate tests of inversions of the tipper and the TE and TM modes were carried out, following recommendation of Martí (2014), In addition, a joint inversion of the TE, TM modes and tipper was made assigning a high error floor to the tipper according to Brasse et al. (2009) (see Additional files). Eventually, a model that does not include the tipper data was chosen, since the same bodies with a lower RMS were obtained. It should be noted that there are other methodologies to identify anisotropy in the data through dimensional analysis (e.g., WALDIM and Marti et al. 2009) near our study area, and Kapinos (2011) performs forward methodology to model anisotropic layer that explain the anomalous behavior in the data. Therefore, it is clear that the models presented in this study are not ultimate but working with electrical anisotropy is too complicated and there are no computational tools available at the moment.

From the results of 2D and 3D models of synthetic and real data, Chang-Hong et al. (2011) show that it is possible to interpret $2 \mathrm{D}$ profile data using $3 \mathrm{D}$ inversion method, provided that using all components of the impedance tensor, not only a reasonable image beneath the profile but also reasonable pictures of nearby $3 \mathrm{D}$ structure can be obtained.

There are several MT studies, which deliver 3D models from data collected along a 2D profile, for example, Meqbel et al. (2016), Patro and Egbert (2011) and Beka et al. (2016).

For the three-dimensional model, a logarithmic grid was designed according to the order of periods and the maximum depth expected to be reached with each set of data. The growth factor in $x$ and $y$ direction was set at 1.3 while 1.2 was chosen for the depth (Kelbert et al. 2014).

A total of 52 frequencies were used for the impedance tensor and 50 frequencies for the tipper. The smoothing factor was set at 0.7, according to Slezak et al. (2019) with small values $(0.3,0.4)$ the inversion algorithm fits the transfer functions by modifying only the small local surface structures. The error floor was $7 \%\left|Z_{x x} Z_{y y}\right|^{1 / 2}$ and 5\% $\left|Z_{x y} Z_{y x}\right|^{1 / 2}$ and the tipper $\left(T_{z x}\right.$ and $\left.T_{z y}\right)$ was 0.05 (absolute value), as a result of the better quality of the data present in the components outside the diagonal and the Tipper. For this model, the bathymetry of the Pacific Ocean was taken into account, this was downloaded from the National Oceanic and Atmospheric Administration and with an electrical resistivity defined at $0.3 \Omega \mathrm{m}$.

Tests were performed including and excluding the Nazca plate in the 2D and 3D grids of the a priori models (see Additional files), the Nazca plate was drawn as a layer of $9.000 \Omega \mathrm{m}$ taking into account the study of Cordell et al. (2019), resistivity with the depths indicated in the study by Tassara and Echaurren (2012) that presents a model of the depth of the Slab, the continental moho and the contact between lithosphere and asthenosphere in our study zone. We observed that the bodies generated in each case were similar in location, magnitude and shape; however, we obtained better RMS in the models that did not include the Nazca plate.

Finally, we performed sensitivity analyses in both models obtained to validate the need of each body within the model for the final fit of the curves of each station.

The sensitivity analysis consists of eliminating the structure and studying the response of the model through forward modeling. The response of the new model is compared with the response of the original model to investigate how it is modified when a body is removed. If the variation influences different stations and the size and distance to the location of the body is consistent with the perceived fluctuation in the curves of each site, it can be concluded that the body is necessary for the fit of the observed data (see Additional files).

\section{Result}

The two-dimensional model (Fig. 4) was fitted with an RMS of $1.88 \%$ after 200 iterations. In it, several conductive and resistive bodies can be observed that can be roughly related to the known geology and tectonics of the zone. In Fig. 4, the resistive body R1, with values between 1000 and $8000 \Omega \mathrm{m}$, is intrinsically related to the subducting Nazca plate; it must be taken into account that the plate has a resistivity decrease at $50 \mathrm{~km}$ depth (between BA03 and BA02 sites). R2, on the other hand, is a highly resistive body, located under the Osorno volcano and between the Llanquihue and Todos Los Santos Lakes. It is located within the continental crust, from a shallow depth to $\sim 20 \mathrm{~km}$. Conductive "C" bodies are often related to fluids, hot zones, salt-water bodies, etc. Towards the west of the profile, in the central depression, two conductive bodies appear, shallow $\mathrm{C} 1$ and $\mathrm{C} 2$ and with resistivity of 1 and $7 \Omega \mathrm{m}$ respectively. Towards the east of the profile, near the Tronador volcano, a body 


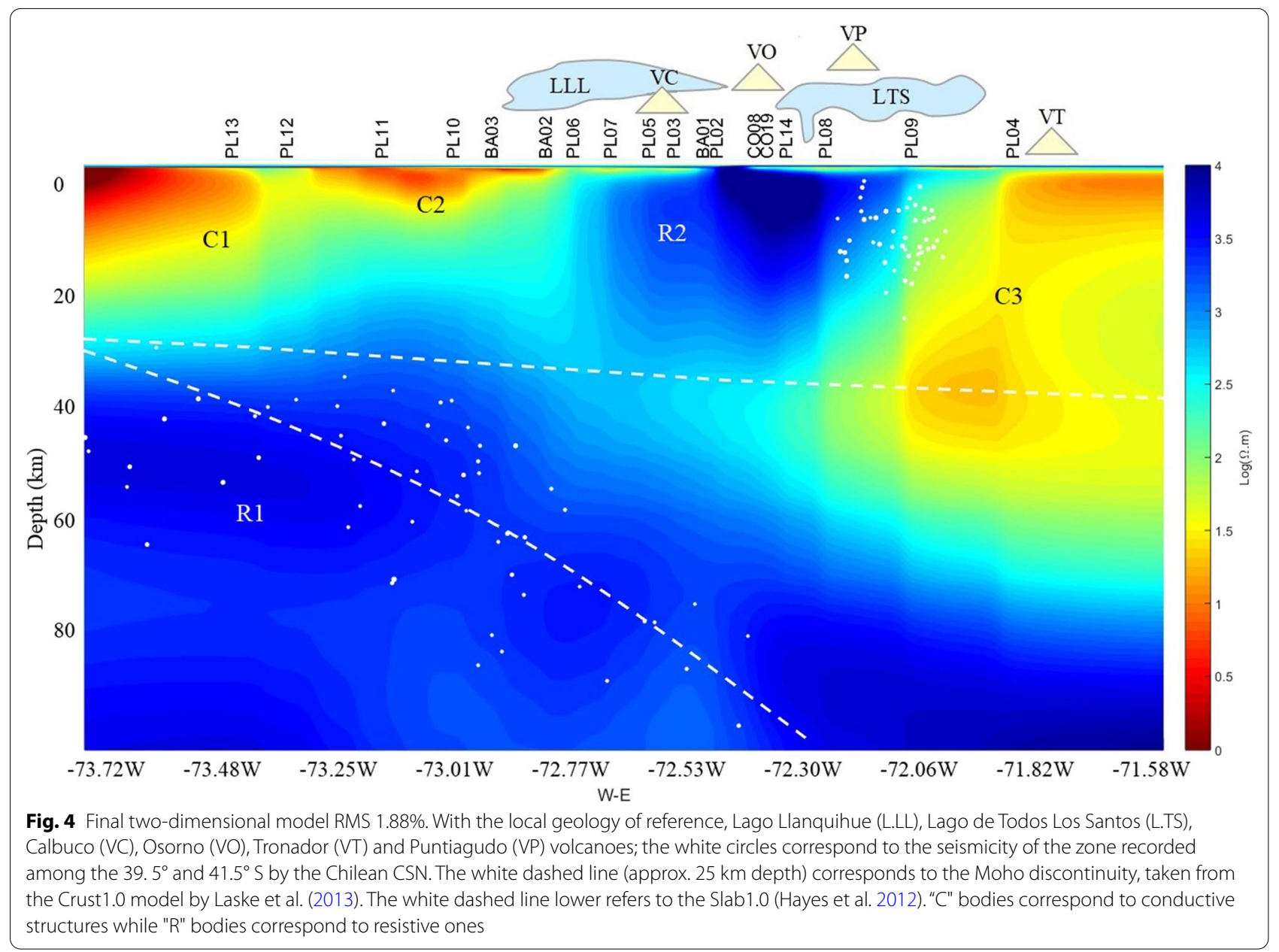

"C3" is observed that crosses the earth's crust, from the mantle, with a resistivity of between 13 and $50 \Omega \mathrm{m}$. In magnetotellurics, broadband data has better resolution for shallow depths while long-period data has better resolution for greater depths. Although the present work inverted models with both broadband and long-period data, it should be noted that the periods used for broadband stations were $\geq 10^{1} \mathrm{~s}$, so it is not expected to obtain high resolution of the surface bodies.

It is believed that the seismicity in the South of Chile is quite lower, compared to the seismicity rate of the rest of the country. Several authors such as Agurto-Detzel et al. (2014) and Lange et al. (2008) affirm that the seismicity of this zone is dominated mainly by the Liquiñe Ofqui fault system. By plotting the seismicity registered since 2013 in our electrical resistivity image, it is easy to notice the accommodation of the earthquakes in the subduction zone and in the zone where the fault system is believed to cross the latitude of the profile.

In the three-dimensional model, Fig. 5 shows three cross-sections parallel to the station profile (located in
Fig. 5d). In this model, different conductive and resistive bodies can be seen below and outside the profile. There is a good correlation with the bodies " $C$ " and " $R$ " generated by the $2 \mathrm{D}$ inversion with the bodies generated by the 3D inversion being $\mathrm{C} 5, \mathrm{C} 6$ and $\mathrm{C} 7$ three conductive bodies that only appear in the $3 \mathrm{D}$, this could be due to the fact that in the two-dimensional model the value of the resistive R2 is very high and fades the resistivity value of these bodies. The reason why some bodies are shown in the $2 \mathrm{D}$ inversion, even when they are outside the profile, according to the 3D model, may be due to a high resistivity contrast between these bodies and the resistivity below the stations, for example, $\mathrm{C} 1$ and $\mathrm{C} 2$.

It is also possible that the location of the bodies outside the profile in the $3 \mathrm{D}$ model is related to the influence of the tipper that was discarded in the 2D inversion due to structural electrical anisotropy. However, there are studies such as the one by Slezak et al. (2016), located in the Northwest of Poland where, without having evidence of structural electrical anisotropy in the crust, they obtain 


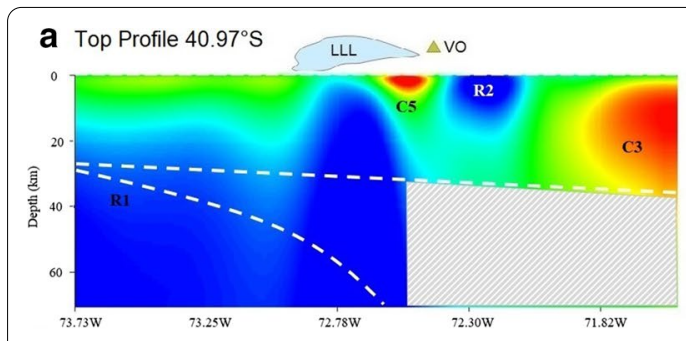

C Central Profile $41.17^{\circ} \mathrm{S}$

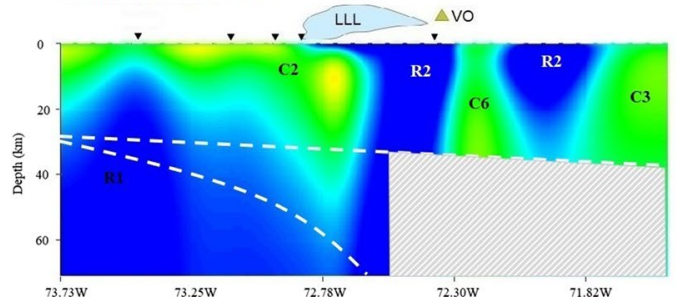

b Lower Profile $41.29^{\circ} \mathrm{S}$

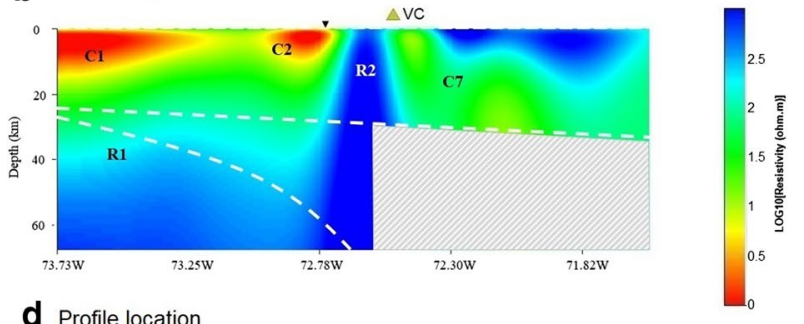

d Profile location

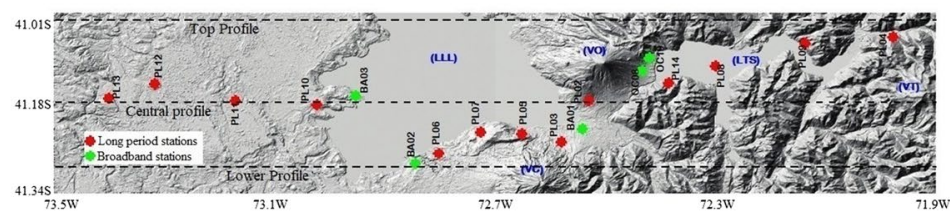

Fig. 5. 3D model profiles RMS $1.95 \%$ a top profile $40.97^{\circ} \mathrm{S}, \mathbf{b}$ Central profile $41.17^{\circ} \mathrm{S}, \mathbf{c}$ lower profile $41.29^{\circ} \mathrm{S}$. Location of the profiles shown in $\mathbf{d}$. Hatched zones are related to poor resolution

in the $3 \mathrm{D}$ model conductive bodies outside the profile that are not evident in the 2D model.

An example of data fit of the 2D and 3D models is shown in Fig. 6 were we include the stations with better and worse fit.
The model we chose to interpret and discuss corresponds to the 3D model, with a RMS $1.95 \%$ (see data fit in Fig. 6a), because it covers all the bodies shown in the 2D model and additionally provides other bodies that converge well with the geology of the zone. The

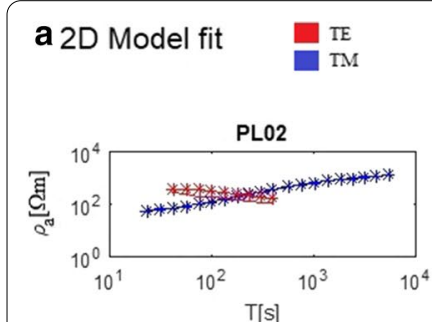

$\mathrm{T}[\mathrm{s}]$
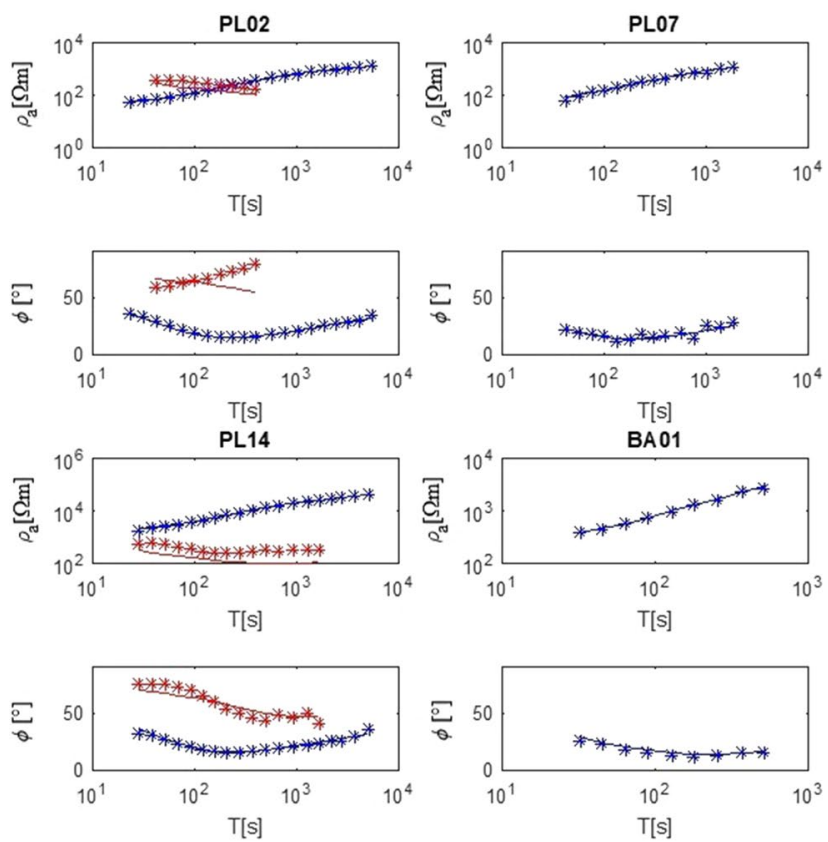

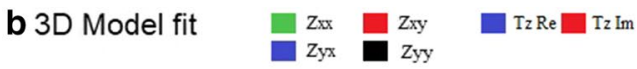
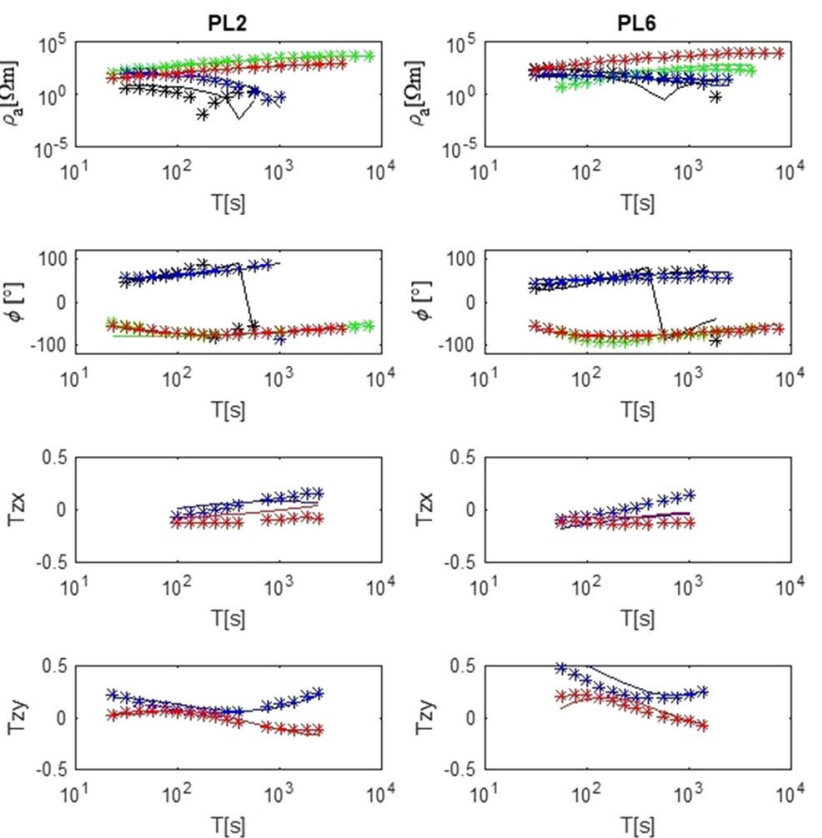

Fig. 6 To make the comparison between measured data (asterisk) and model response (continuous lines) at four exemplary sites. a 3D model fit curves best and worst fitting curves. $\mathbf{b} 2 \mathrm{D}$ model fit curves best and worst fitting curves 
three-dimensional model was obtained with all the available information from the impedance tensor and tipper.

\section{Discussion}

R1 has been identified as a regional body at great depths related to the Nazca plate that subducts under the South American plate and its decrease in resistivity at $50 \mathrm{~km}$ depth is related to the process of serpentinization by an early dehydration of the Slab. This serpentinization of the mantle produces an increase in porosity that leads to a decrease in electrical resistivity, which can be further reduced by the production of electrically conductive magnetite networks (Stesky and Brace 1973). The Nazca plate has been determined by several long-term magnetotelluric studies, in the South Central and Southern zone of Chile, for example, Brasse et al. (2009), Kapinos et al. (2016) and Cordell et al. (2019). On the other hand, Worzewski et al. (2011) with a study of MT in Central America where the Nazca, Cocos and Caribbean plates interact observe this important decrease in resistivity in the same zone where DeShon et al. (2006) observe a decrease in the $\mathrm{S}$ wave velocities, both studies propose that this is a zone of serpentinization of the mantle.

Below the Central Valley, conductive anomalies formed by bodies $\mathrm{C} 1$ and $\mathrm{C} 2$ are located superficially in the crust, just above where the Nazca plate discontinuity appears. In the three-dimensional model (see central profile), body $\mathrm{C} 2$ seems to migrate from the mantle, the body extends from the Moho to the surface; this conductor body is probably the result of fluids released from prograde metamorphism of clay-rich oceanic upper crustal sediments. We relate these bodies to the early dehydration of the slab, in this process, water bound to the pores is expelled from the subducting slab to shallow depths by compaction and lithification (Peacock 1990).

The result of a seismic profile almost coincident with our magnetotelluric profile in the zone of the Central Valley, studied by Jordan et al. (2001), shows some seismic reflectors in the zone where bodies $\mathrm{C} 1$ and $\mathrm{C} 2$ are observed that relate to faults at a depth not greater than $10 \mathrm{~km}$, and we could affirm that these faults are facilitating the migration and distribution of fluids in the Central Valley.

The C3 anomaly can be interpreted as a zone of fluid accumulation resulting from a partial fusion related to the Nazca plate serpentinization or eclogitization process and high pressure and temperature conditions at depth. Numerical models by Völker and Stipp (2015) suggest that approximately $50 \%$ of the water intake fluids from the crust and mantle are released in the front arc or rear arc, this could explain why the C3 conductor is much larger than the other conductors and why it is located more to the east of the profile. However, to constrain the east extension of this body, more measurements are needed towards the Argentina mountain range side. This important conductivity anomaly is comparable to anomalies found in studies conducted in other zones that have developed typical surface expressions such as volcanic arcs around the world, e.g., magnetotelluric studies in British Columbia (Soyer and Unsworth 2006), in Oregon (Cascadia) (Jiracek and Curtis 1989), in Mexico (Jödicke et al. 2006), in Northern Chile (Schwalenberg et al. 2002) and (Brasse et al. 2002), in Greece (Galanopoulos et al. 2005), in Japan (Nankai) (Ichiki et al. 2000) and (Ryukyu Trench) (Shimakawa and Honkura 1991), in Costa Rica (Worzewski et al. 2011), in Central and Southern Chile (Cordell et al. 2019), (Brasse et al. 2009) and (Kapinos et al. 2016).

The C5 body with resistivities around $1 \Omega \mathrm{m}$ located north of the Osorno volcano at a depth less than $10 \mathrm{~km}$ could be related to an active magmatic or hydrothermal system associated with the volcano, its such low resistivity values correlate well with a conductive zone of molten mass accumulation. The report of volcanic activity in the Los Lagos region (SERNAGEOMIN, n.d.) has recorded multiple seismic activity between 2017 and 2019, related to the Osorno volcano. Most of the seismic events have been located towards the Northwest of the volcano at depths of less than $10 \mathrm{~km}$, coinciding with the location of the anomaly, however, taking into account that the last volcanic eruption dates back to 1835 and that the information in the reports is neither exact nor sufficient to analyze the focal mechanisms and confirm that the events are typical of the volcano, nad we can affirm that these events are attributed to the Liquiñe Ofqui Fault System. An important consideration relates to the effect of including or excluding topography in inversion algorithms. For the Merapi volcano, located in Indonesia, Müller and Haak (2004) show that the induction vectors suggest a conductive structure centered in the volcano that they attribute to the high topography of its cone, that is, in these cases special care must be taken to differentiate how much of the response of the induction vector is due to the topography and how much to the conductivity of the rock. Brasse and Eydam (2008) also analyze the topographic effect on volcanic buildings with a high slope, finding that the inversions create artifacts related to a static displacement in the electric field resulting from the effect of the topography. According to the above and knowing that in the 2D and 3D models of our study the topography was not included, it is very likely that C5 is simply an artifact created by the inversion software as an effect of the topography of the cone of the Osorno volcano. In addition, a broadband MT study on the Osorno volcano by Diaz et al. (2020) confirms that this anomaly does not exist. 
The anomaly named $\mathrm{C} 6$, located to the east of the Osorno volcano, coincides with the location of the Liquiñe Ofqui fault zone at $72.28^{\circ} \mathrm{W}$ in length and $41.17^{\circ} \mathrm{S}$ latitude (see Fig. 5c). The elongated shape of this body supports well the idea that it is a fluid ascent facilitation conduit due to a fractured weakness zone related to the fault system. The papers by Cembrano and Lara (2009) and Perez-Florez et al. (2017) confirm that transverse strike-slip faults are oriented favorably with respect to the stress field and promote vertical migration of magma. It should be noted that the C6 body, in our model, does not present resolution for depths greater than $20 \mathrm{~km}$. This trace of the fault is also observed in the study of Zuñiga Armijo (2019), by means of broadband magnetotelluric measurements, Zuñiga Armijo (2019) proposes that this fault is facilitating the ascent of fluids towards a mush type reservoir of the Osorno volcano.

The C7 anomaly shown in the three-dimensional inversion is a conductive body, located under Calbuco volcano that could be interpreted as a magmatic reservoir of depth between 10 and $20 \mathrm{~km}$ that is connected to a conduit or structure of the Andean transverse faults and that is directed towards the trace of the Liquiñe Ofqui fault.

According to Selles and Moreno (2011), the Calbuco volcano does not present evidence of being located on an important regional structure, however, Perez-Florez et al. (2017) outline some guidelines of the Andean Transverse Fault system, which present orientation not located in the southern volcanic zone of the Andes. Lerner et al. (2020) state that magma reservoirs are often horizontally offset from their associated volcanic edifices by multiple kilometers, the inferred magma reservoir centroids occur outside of the overlying volcano's mean radius.

Morgado et al. (2019) through a petrochemical study of samples from the Calbuco eruption in 2015, propose the existence of a mush type deposit, located in the upper crust up to 5.5-9.5 km deep. Delgado et al. (2017) suggest a pressurized flattened spheroid shape for the reservoir below the Calbuco volcano through modeling of the co-eruptive subsidence signal. Considering the 2015 lava flows, Morgado et al. (2019) restricted the pre-eruptive conditions to: temperature $900-1060{ }^{\circ} \mathrm{C}$, pressure 2-6 kbar, $2-4 \% \mathrm{H} 2 \mathrm{O}$ and a variable amount of $\mathrm{SiO}_{2}$ between 55.6 and 56.9\%. Castruccio et al. (2016) calculated $\mathrm{SiO}_{2}$ between 54 and $55 \mathrm{wt} \%$ and $\mathrm{Na}_{2} \mathrm{O}$ between 3.6 and $3.8 \%$, $4-5 \% \mathrm{H}_{2} \mathrm{O}$ and pressures of $180-240 \mathrm{MPa}$.

Using the SIGMELTS web application (Pommier and Le-Trong 2011), a model was built with the above parameters, estimating an electrical resistivity of the variable magmatic reservoir between 2 and $10 \Omega \mathrm{m}$, which could be an indicator that our C7 anomaly is less deep and more conductive.
There is a difference in the composition of the products in the two volcanoes: the Osorno is predominantly basaltic while the Calbuco is andesitic. However, ground, petrographic and geochemical observations suggest that the andesitic composition of the Calbuco is the result of a contamination of subcortical basaltic magmas with magmas generated at the cortical level (Lopez-Escobar et al. 1992). Thus, the difference between the composition of the Osorno and Calbuco products could be explained by an apparent differentiation of the magma that has to travel a greater distance to reach the volcanic reservoir, or perhaps it could also be due to the fact that the magmatic material of this volcano has a longer residence time in the crust than the rest of the volcanic centers in the southern zone of the Andes.

Finally, the highly resistive R2 is correlated with the North Patagonian Batholith, a granitic basement widespread mainly on the southeast and west sides of the Osorno volcano.

The North Patagonian Batholith includes granites, granodiorites, diorites and tonalites, and felsic igneous rocks that range resistivities values from 1000 to $100,000 \Omega \mathrm{m}$ according to Palacky (1987).

\section{Conclusions}

Based on 2D and 3D inversions of magnetotelluric data in a period range of $10^{1}-10^{4} \mathrm{~s}$, collected through a profile of 19 sites located between the Central Valley and the Andes mountain range at latitude $\sim 41^{\circ} \mathrm{S}$, we derived the lithospheric-scale resistivity model of the subduction zone of the Southern Andes.

Different models and dimensional parameters were generated to circumvent the effect of the electrical structural anisotropy detected in the data. Data fit is generally good and together with the results of the sensitivity tests, we confirmed the robustness of the interpreted model.

The deep electrical resistivity image allowed us to analyze different volcano processes that occur thanks to subduction, in the Southern Zone of the Andes. In our model, it was possible to observe the process of serpentinization of the mantle with the early dehydration of the slab marked as an important decrease of resistivity in the Nazca plate at a depth of approximately $50 \mathrm{~km}$, in addition, conductive fluids $(\mathrm{C} 1, \mathrm{C} 2)$ were observed located in the crust just at the top of where the mantle wedge should be serpentinizing as a result of the dehydration of the slab. The location of the conductors under the Central Valley suggests that the release of fluids occurs continuously at different depths during the mineralogical changes presented in the Nazca plate in the development of its subduction.

The position of the large conductor (C3) in the main mountain range is similar to that found by various 
magnetotelluric studies around the world in subduction zones and which they interpret as a zone of fluid accumulation, generated by a partial fusion related to the phenomenon of eclogitization of the plate that can occur at different depths depending on the degree of hydration or age of the slab.

Other processes of migration and accumulation of fluids through the continental crust were identified in our resistivity image, such as the C5, C6 and C7 anomalies, associated with the Osorno Calbuco volcanoes and the fault systems that dominate the zone. The C5 anomaly that was initially associated with a magmatic chamber located 10-km deep northwest of the Osorno volcano was finally discarded and interpreted as an artifact created by the inversion of the volcanic cone topography. Since in the study by Diaz et al. (2020), which has better resolution for shallow bodies by the used broadband data and more density of stations in the northern zone of the volcano, this body does not exist.

C6 coincided with the location of a trace of the Liquiñe Ofqui Fault Zone, because of its elongated shape and resistivity values, this anomaly was interpreted as a conduit through which the transport and ascent of fluids is being facilitated and which perhaps communicates with some pre-Andean (Permian-Paleozoic) lineage, belonging to the Andean Transverse Fault system that could be connected in turn to the Calbuco volcano by means of the anomaly (C7), thus explaining the discrepancy between the composition of the lava of the Calbuco and Osorno volcanoes by an apparent differentiation of the magma that has to travel a greater distance and by a different fault system to reach the Calbuco volcanic reservoir.

\section{Supplementary Information}

The online version contains supplementary material available at https://doi. org/10.1186/s40623-020-01332-w.

Additional file 1: Anisotropy. a) 2D test model including Tipper with high error. b) Phase escaping from its original quadrant, behavior related to the presence of anisotropy in the data.

Additional file 2: Nazca Plate. a) 3D model with and without Nazca plate as a priori model. b) 2D model with and without Nazca plate as a priori model.

Additional file 3: Sensivity. Sensitivity analysis. a) Body C2-2D model. b) Bodies C6 and C5-3D model.

\section{Abbreviations}

SVZ: Southern Volcanic Zone of the Andes; LOFZ: Liquiñe Ofqui Fault Zone; L. LL: Llanquihue Lake; L.TS: Todos Los Santos Lake; ATF: Andean Transverse Fault; MT: Magnetotellurics; TM: Magnetic transverse; TE: Electric transverse; ADU: Analog/Digital Signal Conditioning Unit; NIMS: Narod Intelligent Magnetotelluric Systems; VO: Osorno volcano; VC: Calbuco volcano; VP: Puntiagudo volcano; VT: Tronador volcano; RMS: Normalized root mean square; 2D: Two dimensional; 3D: Three dimensional; CSN: Centro Sismológico Nacional de Chile.

\section{Acknowledgements}

This research was funded by PIA/CONICYT Anillo ACT-172002 and FONDECYT 1170195. We thank the Andean Geothermal Center of Excellence (FONDAPCEGA, 15090013) for the support with the Metronix equipment used in the field campaigns. We thank Martyn Unsworth and Darcy Cordell (U. Alberta, Canada) for the support with NIMS equipment used for the long-period MT data collection. Special thanks to the people who supported the field data collection: Eric Cardenas, Felipe Cordoba, Maria José Hernandez, Miguel Medina, Gustavo Perez, Gabino Reginato and Vicente Yañez. This research was partially supported by the supercomputing infrastructure of the NLHPC (ECM-02). The authors are grateful to the editor and to J. Ledo and to the second anonymous reviewer for their insightful comments and suggestions.

\section{Authors' contributions}

The co-authors supported field data collection, data analysis and geological interpretation of the models.

\section{Funding}

This research was funded by PIA/CONICYT Anillo ACT-172002 and FONDECYT 1170195.

\section{Availability of data and materials}

In the following link, reviewers can view information supporting the research. Only they can access the data for information purposes. This information is private and cannot be reproduced or modified. This information can only be seen by the reviewers of the paper for information purposes. The information will be published once the article is accepted and published in the journal. https://osf.io/zsqjc/?view_only=c606c5b2ba7a4991a539630d7e876d5f

\section{Ethics approval and consent to participate}

No applicable.

\section{Consent for publication}

No applicable.

\section{Competing interests}

We have no conflict of interest in this investigation.

\section{Author details}

${ }^{1}$ Departamento de Geofísica, Universidad de Chile, Blanco Encalada 2002, Santiago, Chile. ${ }^{2}$ Centro de Excelencia en Geotermia de Los Andes, Plaza Ercilla 803, Santiago, Chile.

Received: 19 August 2020 Accepted: 6 December 2020

Published online: 04 January 2021

\section{References}

Agurto-Detzel H, Rietbrock A, Bataille K, Miller M, Iwamori H, Priestley K (2014) Seismicity distribution in the vicinity of the Chile Triple Junction, Aysén Region, southern Chile. J S Am Earth Sci 51:1-11

Angermann D, Klotz J, Reigber C (1999) Space-geodetic estimation of the Nazca-South America Euler vector. Earth Planet Sci Lett 171(3):329-334

Beka TI, Smirnov M, Birkelund Y, Senger K, Bergh SG (2016) Analysis and 3D inversion of magnetotelluric crooked profile data from central Svalbard for geothermal application. Tectonophysics 686:98-115

Brasse H, Eydam D (2008) Electrical conductivity beneath the Bolivian Orocline and its relation to subduction processes at the South American continental margin. J Geophys Res 113:B07109. https://doi.org/10.1029/2007J B005142

Brasse H, Lezaeta P, Rath V, Schwalenberg K, Soyer W, Haak V (2002) The Bolivian Altiplano conductivity anomaly. J Geophys Res 107(B5):EPM 4-1-EPM 4-14. https://doi.org/10.1029/2001JB000391

Brasse H, Kapinos G, Li Y, Mütschard L, Soyer W, Eydam D (2009) Structural electrical anisotropy in the crust at the South-Central Chilean continental 
margin as inferred from geomagnetic transfer functions. Phys Earth Planet Inter 173(1-2):7-16

Castruccio A, Clavero J, Segura A, Samaniego P, Roche O, Le Pennec J-L, Droguett B (2016) Eruptive parameters and dynamics of the April 2015 sub-Plinian eruptions of Calbuco volcano (southern Chile). Bull Volcanol 78(9):62. https://doi.org/10.1007/s00445-016-1058-8

Cembrano J, Hervé F (1993) The Liquine Ofqui fault zone: a major Cenozoic strike slip duplex in the Southern Andes. Géodynamique Andine Symp Int 21-23:175-178

Cembrano J, Lara L (2009) The link between volcanism and tectonics in the southern volcanic zone of the Chilean Andes: a review. Tectonophysics 471(1-2):96-113

Cembrano J, Hervé F, Lavenu A (1996) The Liquiñe Ofqui fault zone: a long-lived intra-arc fault system in southern Chile. Tectonophysics 259(1-3):55-66

Chang-Hong L, Han-Dong T, Tuo T (2011) The possibility of obtaining nearby 3 D resistivity structure from magnetotelluric $2 \mathrm{D}$ profile data using $3 \mathrm{D}$ inversion. Chin J Geophys 54(1):72-83

Clemens JD, Mawer CK (1992) Granitic magma transport by fracture propagation. Tectonophysics 204(3-4):339-360

Cordell D, Unsworth MJ, Diaz D, Reyes-Wagner V, Currie CA, Hicks SP (2019) Fluid and melt pathways in the Central Chilean Subduction Zone near the 2010 Maule earthquake $\left(35-36^{\circ} \mathrm{S}\right)$ as inferred from magnetotelluric data. Geochem Geophys Geosyst 20(4):1818-1835

Delgado F, Pritchard ME, Ebmeier S, González P, Lara L (2017) Recent unrest (2002-2015) imaged by space geodesy at the highest risk Chilean volcanoes: Villarrica, Llaima, and Calbuco (Southern Andes). J Volcanol Geoth Res 344:270-288

DeShon HR, Schwartz SY, Newman AV, González V, Protti M, Dorman LM, Dixon TH, Sampson DE, Flueh ER (2006) Seismogenic zone structure beneath the Nicoya Peninsula, Costa Rica, from three-dimensional local earthquake P-and S-wave tomography. Geophys J Int 164(1):109-124

Díaz D, Zuñiga F, Castruccio A (2020) The interaction between active crustal faults and volcanism: A case study of the Liquiñe-Ofqui Fault Zone and Osorno volcano, southern Andes, using magnetotellurics. J Volcanol Geoth Res 393:106806. https://doi.org/10.1016/j.jvolgeores.2020.106806

Egbert G (1997) Robust multiple-station magnetotelluric data processing. Geophys J Int 130(2):475-496

Egbert G, Booker J (1986) Robust estimation of geomagnetic transfer functions. Geophysics 87(1):173-194

Egbert G, Livelybrooks D (1996) Single station magnetotelluric impedance estimation: coherence weighting and the regression M-estimate. Geophysics 61(4):937-1240

Evans RL, Wannamaker PE, McGary S, Elsenbeck J (2014) Electrical structure of the central Cascadia subduction zone: the EMSLAB Lincoln Line revisited. Earth Planet Sci Lett 402:265-274

Galanopoulos D, Sakkas V, Kosmatos D, Lagios E (2005) Geoelectric investigation of the Hellenic subduction zone using long period magnetotelluric data. Tectonophysics 409(1-4):73-84

Glodny J, Gräfe K, Echtler H, Rosenau M (2008) Mesozoic to Quaternary continental margin dynamics in South-Central Chile $\left(36-42^{\circ} \mathrm{S}\right)$ : the apatite and zircon fission track perspective. Int J Earth Sci 97(6):1271-1291

Hayes GP, Wald DJ, Johnson RL (2012) Slab1.0: a three-dimensional model of global subduction zone geometries. J Geophys Res 117:B01302. https:// doi.org/10.1029/2011JB008524

Hervé F (1994) The Southern Andes between $39^{\circ}$ and $44^{\circ} \mathrm{S}$ Latitude: the geological signature of a transpressive tectonic regime related to a magmatic arc. In: Reutter KJ, Scheuber E, Wigger PJ (eds) Tectonics of the Southern Central Andes. Springer, Berlin

Hyndman R, Peacock S (2003) Serpentinization of the forearc mantle. Earth Planet Sci Lett 212(3-4):417-432

Ichiki M, Sumitomo N, Kagiy T (2000) Resistivity structure of high-angle subduction zone in the southern Kyushu district, southwestern Japan. Earth Planets Space 52(8):539-548

Jiracek GR, Curtis JH (1989) Two-dimensional magnetotelluric inversion of the EMSLAB Lincoln Line. J Geophys Res 94(B10):14145-14151. https://doi. org/10.1029/JB094iB10p14145

Jödicke H, Jording A, Ferrari L, Arzate J, Mezger K, Rüpke L (2006) Fluid release from the subducted Cocos plate and partial melting of the crust deduced from magnetotelluric studies in southern Mexico: Implications for the generation of volcanism and subduction dynamics. J Geophys Res. https://doi.org/10.1029/2005JB003739

Jordan TE, Burns WM, Veiga R, Pángaro F, Copeland P, Kelley S, Mpodozis C (2001) Extension and basin formation in the southern Andes caused by increased convergence rate: a mid-Cenozoic trigger for the Andes. Tectonics 20(3):308-324

Kapinos G (2011) Amphibious magnetotelluric at the South-Central Chilean continental margin. PhD Thesis. FU Berlin

Kapinos G, Montahaei M, Meqbel N, Brasse H (2016) Three-dimensional electrical resistivity image of the South-Central Chilean subduction zone. Tectonophysics 666:76-89. https://doi.org/10.1016/j.tecto.2015.10.016

Kelbert A, Meqbel N, Egbert N, Tandon K (2014) ModEM: a modular system for inversion of electromagnetic geophysical data. Comput Geosci 66:40-53

Lange D, Cembrano J, Rietbrock A, Haberland C, Dahm T, Bataille K (2008) First seismic record for intra-arc strike-slip tectonics along the Liquiñe-Ofqui fault zone at the obliquely convergent plate margin of the southern Andes. Tectonophysics 455(1-4):14-24

Laske G, Masters G, Ma Z, Pasyanos ME (2013) Update on CRUST1.0: a 1-degree global model of earth's crust. In: Geophysical research abstracts, EGU2013-2658, vol 15. EGU General Assembly, Vienna, Austria

Lavenu A, Cembrano J (1999) Compressional- and transpressional-stress pattern for Pliocene and Quaternary brittle deformation in fore arc and intra-arc zones (Andes of Central and Southern Chile). J Struct Geol 21(12):1669-1691

Leech M (2001) Arrested orogenic development: eclogitization, delamination, and tectonic collapse. Earth Planet Sci Lett 185(1-2):149-159

Lerner AH, O'Hara D, Karlstrom L, Ebmeier SK, Anderson KR, Hurwitz S (2020) The prevalence and significance of offset magma reservoirs at arc volcanoes. Geophys Res Lett 47:e2020GL087856. https://doi. org/10.1029/2020GL087856

Lopez-Escobar L, Parada MA, Moreno H, Frey FA, Hickey-Vargas RL (1992) A contribution to the petrogenesis of Osomo and Calbuco volcanoes, Southern Andes $\left(41^{\circ} 00^{\prime}-41^{\circ} 30^{\prime} \mathrm{S}\right)$ : comparative study. Revista Geológica de Chile 19(2):211-226

Martí A (2014) The role of electrical anisotropy in magnetotelluric responses: from modelling and dimensionality analysis to inversion and interpretation. Surv Geophys 35(1):179-218

Martí A, Queralt P, Ledo J (2009) WALDIM: a code for the dimensionality analysis of magnetotelluric data using the rotational invariants of the magnetotelluric tensor. Comput Geosci 35(12):2295-2303

Mella M, Munoz J, Vergara M, Klohn E, Farmer L, Stern CR (2005) Petrogenesis of the Pleistocene Tronador Volcanic Group, Andean Southern Volcanic Zone. Revista Geológica de Chile 32(1):131-154

Meqbel N, Weckmann U, Muñoz G, Ritter O (2016) Crustal metamorphic fluid flux beneath the Dead Sea Basin: constraints from 2-D and 3-D magnetotelluric modelling. Geophys J Int 207(3):1609-1629

Moreno H, Lara L, Orozco G (2010) Geología del Volcán Osorno. Servicio Nacional de Geología y Minería de Chile, Santiago

Morgado E, Morgan DJ, Harvey J, Parada M-Á, Castruccio A, Brahm R, Gutiérrez F, Georgiev B, Hammond SJ (2019) Localised heating and intensive magmatic conditions prior to the 22-23 April 2015 Calbuco volcano eruption (Southern Chile). Bull. Volcanol 81(4):24

Müller A, HaakV (2004) 3-D modeling of the deep electrical conductivity of Merapi volcano (Central Java): integrating magnetotellurics, induction vectors and the effects of steep topography. J Volcanol Geoth Res 138(3-4):205-222

Navarro A (2019) Caracterización sismotectonica de la cordillera de la costa en Chile Central, entre los $32^{\circ} 30^{\prime} \mathrm{S}$ y los $34^{\circ} \mathrm{S}$, mediante tomografia sismica pasiva. Dissertation, Santiago, Chile: Repositorio Académico Universidad de Chile

Palacky G (1987) Resistivity characteristics of geologic targets. In: Nabighian MN (ed) Electromagnetic methods in applied geophysics. Society of Exploration Geophysicists, Tulsa

Pankhurst R, Rapela C, Fanning C, Marquez M (2006) Gondwanide continental collision and the origin of Patagonia. Earth Sci Rev 76(3-4):235-257

Patro PK, Egbert GD (2011) Application of 3D inversion to magnetotelluric profile data from the Deccan Volcanic Province of Western India. Phys Earth Planet Inter 187(1-2):33-46

Peacock S (1990) Fluid processes in subduction zones. Science 248(4953):329-337 
Pérez-Flores P, Wang G, Mitchell TM, Meredith PG, Nara Y, Sarkar V, Cembrano $J$ (2017) The effect of offset on fracture permeability of rocks from the Southern Andes Volcanic Zone, Chile. J Struct Geol 104:142-158

Pommier A, Le-Trong E (2011) SIGMELTS: a web portal for electrical conductivity calculations in geosciences. Comput Geosci 37(9):1450-1459

Radic JP (2010) Cenozoic basins and their control on volcanism of Nevados de Chillan and Copahue-Callaqui complexes (36-39 S Southern Andes). Revista Geológica de Chile 37(1):220-246

Reynard B, Mibe K, Van de Moortele B (2011) Electrical conductivity of the serpentinised mantle and fluid flow in subduction zones. Earth Planet Sci Lett 307(3-4):387-394

Rodi W, Mackie R (2001) Nonlinear conjugate gradients algorithm for 2-D magnetotelluric inversion. Geophysics 66(1):174-187

Saffer DM (2017) Mapping fluids to subduction megathrust locking and slip behavior. Geophys Res Lett 44:9337-9340

Schwalenberg K, Rath V, Haak V (2002) Sensitivity studies applied to a twodimensional resistivity model from the Central Andes. Geophys J Int 150(3):673-686

Selles D, Moreno H (2011) Geología del Volcán Calbuco. Servicio Nacional de Geología y Minería de Chile, Santiago

SERNAGEOMIN, s.f. Ministerio de Mineria, Gobierno de Chile, Reporte de actividad volcánica.

Shimakawa Y, Honkura Y (1991) Electrical conductivity structure beneath the Ryukyu Trench-Arc system and its relation to the subduction of the Philippine Sea Plate. J Geomagn Geoelectr 43(1):1-20

Slezak K, Jozwiak W, Nowozynski K, Brasse H (2016) 3-D inversion of MT data for imaging deformation fronts in NW Poland. Pure Appl Geophys 173(7):2423-2434

Slezak K, Jozwiak W, Nowozynski K, Orynski S, Brasse H (2019) 3-D studies of MT data in the Central Polish Basin: influence of inversion parameters, model space and transfer function selection. J Appl Gephys 161:26-36

Smith T (1995) Understanding telluric distortion matrices. Geophys J Int 122(1):219-226

Soyer W, Unsworth M (2006) Deep electrical structure of the northern Cascadia (British Columbia, Canada) subduction zone: Implications for the distribution of fluids. Geology 34(1):53-56

Stesky R, Brace W (1973) Electrical conductivity of serpentinized rocks to 6 kilobars. J Geophys Res 78(32):7614-7621
Tassara A, Echaurren A (2012) Anatomy of the Andean subduction zone: threedimensional density model upgraded and compared against global-scale models. Geophys J Int 189(1):161-168

Tassara A, Yañez G (2003) Relación entre el espesor elástico de la litosfera y la segmentación tectónica del margen andino (15-47 S). Revista Geológica de Chile 30(2):159-186

Thomson SN, Hervé F (2002) New time constraints for the age of metamorphism at the ancestral Pacific Gondwana margin of southern Chile (42-52 S). Revista geológica de Chile 29(2):151-165

Tournerie B, Chouteau M, Marcotte D (2007) Magnetotelluric static shift: estimation and removal using the cokriging method. Geophysics 72(1):F25-F34

Völker D, Stipp M (2015) Water input and water release from the subducting Nazca Plate along southern Central Chile $\left(33^{\circ} \mathrm{S}-46^{\circ} \mathrm{S}\right)$. Geochem Geophys Geosyst 16(6):1825-1847

Vozoff K (1991) Electromagnetic methods in applied geophysics-Applications, chapter The magnetotelluric method. 641-711 ed. Society of Exploration Geophysicists II

Wannamaker PE, Evans RL, Bedrosian PA, Unsworth MJ, Maris V, McGary RS (2014) Segmentation of plate coupling, fate of subduction fluids, and modes of arc magmatism in Cascadia, inferred from magnetotelluric resistivity. Geochem Geophys Geosyst 15(11):4230-4253

Wiese H (1962) Geomagnetische Tiefentellurik Teil II: Die Streichrichtung der Untergrundstrukturen des elektrischen Widerstandes, erschlossen aus geomagnetischen Variationen. Pure Appl Geophys 52:83-103

Worzewski T, Jegen M, Kopp H, Brasse H, Castillo WT (2011) Magnetotelluric image of the fluid cycle in the Costa Rican subduction zone. Nat Geosci $4(2): 108-111$

Zuñiga Armijo F (2019) Estructuras Magmaticas bajo el Volcán Osorno, identificadas mediante Magnetotelurica. Dissertation, Santiago, Chile: Repositorio Universidad de Chile

\section{Publisher's Note}

Springer Nature remains neutral with regard to jurisdictional claims in published maps and institutional affiliations.

\section{Submit your manuscript to a SpringerOpen ${ }^{\circ}$ journal and benefit from:}

- Convenient online submission

- Rigorous peer review

- Open access: articles freely available online

- High visibility within the field

- Retaining the copyright to your article

Submit your next manuscript at springeropen.com 